\title{
Oštećenja, lomljenje i preoblikovanje: recikliranje i sekundarna upotreba predmeta od keramike
}

Jasna Vulković

DOI: $10.17234 / 9789531757232-04$

Keramika, kao najbrojnija vrsta nalaza na arheološkim nalazištima gotovo svih perioda, od najranijih perioda praistorije pa sve do danas vrsta je materijala sa veoma širokom upotrebom: od posuđa, preko predmeta za svakodnevnu upotrebu i različitih kultnih, pa i ukrasnih predmeta, sve do građevinskog materijala (opeka, crep, cevi). Većina arheoloških razmatranja, međutim, zasniva se na stilsko-tipološkom ili funkcionalnom opredeljenju keramičkih predmeta, pritom često zapostavljajući veoma važne aspekte u njihovom životnom ciklusu, odnosno «životu» predmeta - od nabavke sirovine, preko izrade, upotrebe do odbacivanja (Schiffer 1983: 681; 1987: 13-15, 271). Svaki predmet se može oštetiti, polomiti, istrošiti, ali to ne znači da on zbog toga izlazi iz upotrebe i da biva odbačen: artefakt tada ulazi u različite, nove vidove svog upotrebnog ciklusa. Kroz ponovnu, sekundarnu upotrebu i recikliranje, njegov upotrebni vek se produžava. Tako keramički predmeti "cirkulišu” kroz različite kontekste upotrebe i učestvuju u nizu aktivnosti da bi konačno stigli do nas tokom iskopavanja kao deo keramičkog asemblaža.

Pojmovi ponovne, sekundarne upotrebe i recikliranja teorijski su detaljno razmotrena i definisana u okviru bihevioralne arheologije, ispitivanjem različitih procesa u kojima artefakti ulaze u arheološki zapis, a koji su posledica različitih aktivnosti. Ponovna upotreba predstavlja promenu korisnika, namene ili forme predmeta (Schiffer 1987: 26), ili "upotrebu nekog predmeta u sekundarnom kontekstu, kada više ne može da služi svojoj originalnoj funkciji” (Deal \& Hagstrum 1995: 111). Drugim rečima, to je svaki vid korišćenja nekog predmeta ili nekog njegovog dela koje sledi posle njegove inicijalne upotrebe, u neku sasvim drugu svrhu, drugačiju od one za koju je predmet isprva osmišljen. Sekundarna upotreba i recikliranje predstavljaju različite varijante ponovne upotrebe: promenu namene predmeta bez modifikacije njegovog oblika, odnosno vraćanje predmeta u proces izrade (Schiffer 1987: 28-32). Situacije u kojima se predmeti od keramike i njihovi fragmenti kreću kroz različite kontekste upotrebe su, međutim, često veoma složene. Zato je ovaj model životnih ciklusa u nekoliko navrata bio redefinisan, da bi se bolje objasnile i razumele specifičnosti keramike iz različitih perioda. Poseban problem uočen je u vezi s pitanjem vraćanja predmeta u proces izrade, a naročito u vezi s korišćenjem fragmenata polomljenih posuda, koji mogu, ali i ne moraju biti dodatno oblikovani. Na primeru neolitske vinčanske keramike, razlika između ponovne i sekundarne upotrebe i recikliranja utvrđena je na osnovu stepena fragmentacije, dok su intervencije u smislu preoblikovanja od sekundarne važnosti. Tako je sekundarna upotreba definisana kao korišćenje celih, polomljenih ili delimično oštećenih posuda bez dodatnih modifikacija, ponovna upotreba kao korišćenje celih ili delimično oštećenih posuda uz veoma male intervencije oblika i potpuno drugačiju funkciju, a recikliranje kao upotreba fragmenata keramike, sa dodatnim intervencijama ili bez njih, kao alatki ili sirovina (Vuković 2015). U slučaju rimske keramike, pitanje mo- 
difikacije oblika takođe je potisnuto u drugi plan, sekundarna upotreba je kao poseban pojam izostavljena, a ponovnom upotrebom se smatra upotreba koja može biti slična onoj za čiju je svrhu posuda izrađena bez modifikacije oblika, ili drugačija od nje, sa intervencijama ili bez njih, dok recikliranje znači upotreba keramike kao sirovine (Peña 2007: 7-10). Nemogućnost da se svi vidovi sekundarne upotrebe objedine u jedinstveni teorijski model pokazuje koliko su kulturne prakse bile kompleksne, tim pre što mnogi predmeti tokom svog upotrebnog ciklusa i po nekoliko puta mogu da prelaze iz jednog u drugi vid sekundarne upotrebe pre nego što budu konačno odbačeni (Vuković 2015, graph 1). Zbog neusaglašenosti u vezi s definisanjem pojmova sekundarne upotrebe, ponovne upotrebe i recikliranja, na ovom mestu će biti razmotreni različiti načini korišćenja predmeta od keramike pošto su oni izgubili svoju prvobitnu, originalnu funkciju. Imajući u vidu i to da mnogi stupnjevi u upotrebnom ciklusu, kao što su na primer, promena korisnika ili sadržaja neke posude, ne ostavljaju materijalne tragove, od neprocenjivog značaja su i podaci dobijeni etnoarheološkim istraživanjima.

\section{Posude ili njihovi delovi u sekundarnoj upotrebi}

Kada se keramička posuda ošteti ili polomi, ili iz nekog razloga više nije pogodna za svoju primarnu upotrebu, ona može promeniti namenu. Etnoarheološka istraživanja sa Filipina pokazuju, na primer, da posude koje su služile za kuvanje pirinča u jednom trenutku postaju "zasićene" i korisnici smatraju da hrana u njima spremljena dobija neprijatan ukus, pa one menjaju svoju namenu (Skibo 1992). U rimskom periodu bilo je uobičajeno da amfore, posude za transport i skladištenje tečnih namirnica (ulja, vina, garuma) promene tu svoju prvobitnu funkciju i koriste se za skladištenje drugih vrsti namirnica (brašna, maslina ili meda), ili da se koriste kao posude za vodu. Na trgovačkim brodovima, na primer, bile su korišćene da bi se njima skladištile namirnice za posadu ili materijali za održavanje broda, a sličnu namenu su imale i u svakodnevnim aktivnostima, za skladištenje alata ili građevinskog materijala (Peña 2007: 95, 71, 105). Delovi posuda se takođe mogu koristiti u čitavnom nizu aktivnosti u vezi sa poljoprivredom i stočarstvom, zanatskom proizvodnjom i drugim poslovima. U grnčarskom zanatu, posude u sekundarnoj upotrebi koriste se za skladištenje sirovina (gline, pigmenata i vode) (Deal \& Hagstrum 1995: 117), a u proizvodnji keramike bez upotrebe grnčarskog vitla često je korišćenje većih, konveksnih delova polomljenih posuda kao sredstva za rotaciju ili njihovih dna kao neke vrste kalupa (Frank 1994; Gosselain 1992), dok je upotreba keramičkih fragmenata kao izolatora tokom pečenja široka praksa, koja se primenjuje kod različitih načina pečenja - na podu jama ili kao sloj kojim se, zajedno sa granjem, balegom i drugim gorivom prekrivaju posude prilikom redukcionog pečenja. Oštećene posude se ponekad čuvaju kao uzori po kojima će se izrađivati nove (Manibabu 2010: 161), čime se održava kontinuitet keramičkih tradicija. Donji delovi posuda mogu se koristiti kao hranilice ili pojilice za domaće životinje, gnezda za živinu, saksije za cveće, obodi kao zaštita za tek iznikle izdanke od životinja ili mraza (Deal and Hagstrum 1995; Deal 1998: 109), a i za sakupljanje kišnice za svakodnevne poslove u domaćinstvu (Manibabu 2010: 161). Oblici posuda ili njihovi delovi u ovim aktivnostima nisu bili naknadno modifikovani.

Na posudama koje su izašle iz primarne upotrebe mogu biti izvršene blage intervencije kako bi postale pogodne za neke druge namene. Nekoliko takvih primera poznato je iz Vinče. Zdela sa uvučenim obodom, tipična za mlađe faze vinčanske kulture tako je pretrpela probijanje dva naspramna gotovo pravilna kružna otvora na donjem delu recipijenta (Vuković 2015). Postoji mogućnost da se radi o nekoj vrsti poklopca. Prisustvo otvora relativno velikih dimenzija, međutim, takvu interpretaciju dovodi u sumnju, jer bi sadržaj poklopljene posude ostao izložen nepovoljnim uticajima, pa pitanje svrhe i namene ove posude još uvek ostaje otvoreno. Drugi slučajevi, zasad takođe bez adekvatnog objašnjenja uključuju doterivanje oboda finih zdela. 
Moguće je da se radi o posudama čiji se gornji deo polomio, pa takve intervencije zapravo predstavljaju neku vrstu održavanja i popravke. Rimske amfore su takođe bile dodatno doterivane da bi mogle koristiti za neke nove svrhe, između ostalog sečenjem, bušenjem i lomljenjem (za pregled videti: Peña 2007). Probijanjem otvora na zidovima dobijale su se posude koje su mogle služiti za sakupljanje urina u latrinama, koji je kasnije korišćen u proizvodnji boja i kože. U rimskim kamenolomima u istočnom Egiptu zabeležena je i jednistvena zanatska proizvodnja: reč je o radionicama specijalizovanim za prepravljanje amfora u stono posuđe - pehare i zdele. Ovako neobična praksa objašnjena je udaljenošću od urbanih centara i problemima troškova nabavke potrebnog posuđa. Kuhinjsko posuđe i krčazi u vreme kasnog srednjeg veka u zapadnoj Evropi sekundarno je korišćeno u funerarnom kontekstu (Baeten et al. 2014): na recipijentima su probijane perforacije, pa su posude korišćene kao kadionice za tamjan.

\section{Fragmenti u sekundarnoj upotrebi}

Najširu upotrebu imaju fragmenti polomljenih posuda i drugih predmeta od keramike i gotovo je nemoguće pobrojati i navesti sve slučajeve. Oni su korišćeni u svom "prirodnom" obliku, ali se mogu dodatno "doraditi", kako bi se pretvorili u funkcionalne alatke ili predmete za svakodnevnu upotrebu. Etnoarheološka istraživanja pokazuju da se delovi posuda koriste u mnogim aktivnostima u domaćinstvu: kao poklopci tokom pripreme hrane ili kao lopatice za za zahvatanje čvrstih namirnica ili za uklanjanje smeća i pepela iz peći i ognjišta (Deal \& Hagstrum 1995: 114). Ovakvi slučajevi se retko mogu pouzdano identifikovati u arheološkom materijalu. $S$ druge strane, fragmenti na kojima su izvršene modifkacije oblika ili na kojima su prisutni tragovi upotrebe sreću se u gotovo svim periodima, iako im je retko posvećena adekvatna pažnja. Na primer, poznato je korišćenje fragmenata rimskih amfora kao paleta, kandila, ili, ukoliko su na njima probijene rupe - kao cediljki (Peña 2007: 144), dok su praistorijske posude služile kao recipijenti za pečenje hrane, kašike, palete ili poklopci (Hally 1983).

Fragmenti predmeta od keramike mogli su biti korišćeni kao neka vrsta alatki, a posebno skreće pažnju njihova brojnost tokom neolita. S obzirom na to da se radi o neatrakrivnim nalazima, oni su vrlo retko razmatrani, pa još uvek nema dovoljno podataka o njihovoj zastupljenosti na neolitskim nalazištima. Na lokalitetu u Vinči otkriven je znatan broj fragmenata ovakvih nalaza (Vuković 2013b) i oni se mogu podeliti na alatke sa radnom ivicom i alatke sa radnim površinama. Uglavnom se radi o fragmentima finije fakture sa mineralnim primesama i glačanim ili čak poliranim površinama. Ove osobine čine keramiku veoma tvrdom, čime joj obezbeđuju visoku otpornost na abraziju, tj. mehanička oštećenja. Takvi fragmenti mogu imati samo jednu radnu ivicu, koja je formirana verovatno tokom prve upotrebe, ali su prisutni i pažljivo oblikovani, poligonalni primerci (sl. 1).

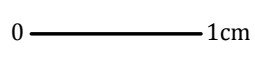

SI. 1: Vinča - poligonalno oblikovana alatka od fragmenta posude (Vuković 2013b: T. I/1).

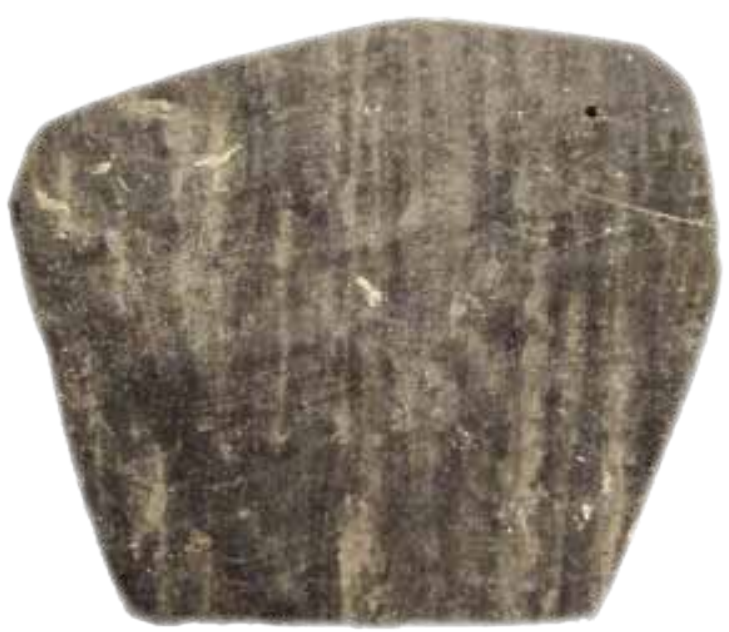



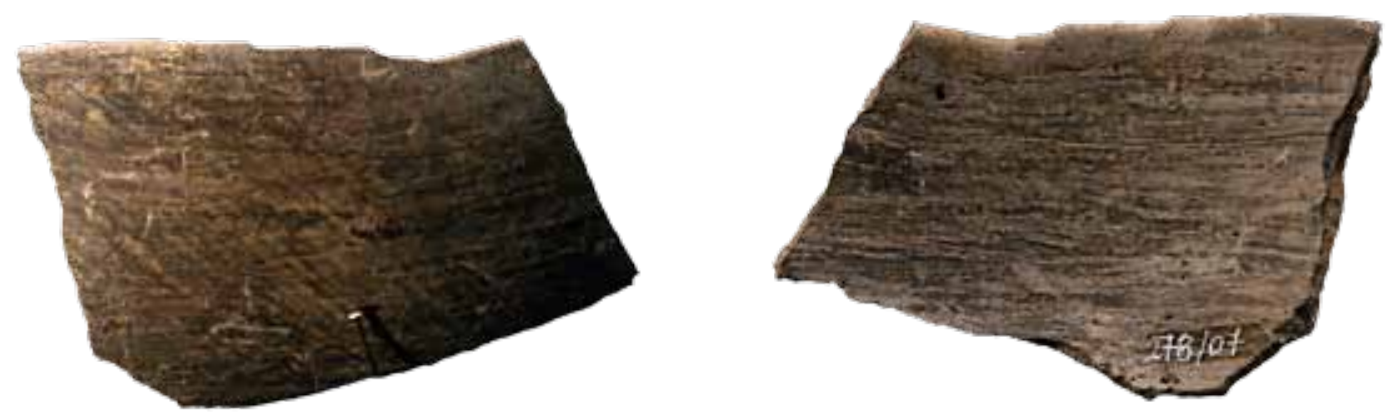

S druge strane, česta je i upotreba oboda finijih zdela (sl. 2), jer su ti ulomci imali "prirodno" zaobljenu jednu ivicu koja je, pošto je posuda polomljena, mogla da služi i kao radna ivica alatke. Kod alatki sa radnim površinama tragovi upotrebe se ne nalaze na ivici fragmenta, već na njegovoj površini. U najvećem broju slučajeva radi se o najisturenijim delovima posude - ramenu zdela, a nešto ređe razgrnutim obodima većih posuda za skladištenje. Prisustvo sličnih alatki od keramičkih posuda poznato je sa praistorijskih lokaliteta iz drugih delova sveta (Lopez Varela et al. 2002; Merkyte 2005; Van Gijn \& Hofman 2008) i one se obično tumače kao alatke koje su služile u procesu izrade keramičkog posuđa - za modifikaciju površine i njeno glačanje, mada postoji i mogućnost da su mogle služiti u procesu prerade biljnih vlakana (Sullivan et al. 1991). Mnoge od njih su mogle biti i multifunkcionalne, o čemu takođe svedoče alatke sa raznovrsnim tragovima upotrebe iz Vinče.

Iako je recikliranje grnčarije zasad najbolje dokumentovano kroz upotrebu fragmenata posuda kao alatki, delovi drugih predmeta od keramike takođe mogu biti korišćeni u različite svrhe. Na primer, zabeležena je upotreba keramičke lopatice kao čekića, o čemu svedoče oštećenja na njenoj površini (Knight 2010: 153). Jedan veoma zanimljiv primer potiče sa neolitskog lokaliteta Pavlovac-Čukar kod Vranja, gde su tokom 2011. godine obavljena velika zaštitna iskopavanja zbog izgradnje auto-puta. Izuzetan je nalaz noge realistično modelovane fino glačane antropomorfne figurine, sa veoma kompleksnim tragovima upotrebe (sl. 3). Radni deo alatke nalazi se na unutrašnjoj strani noge - od gležnja naviše, pa ukoliko razmatramo ovaj primerak
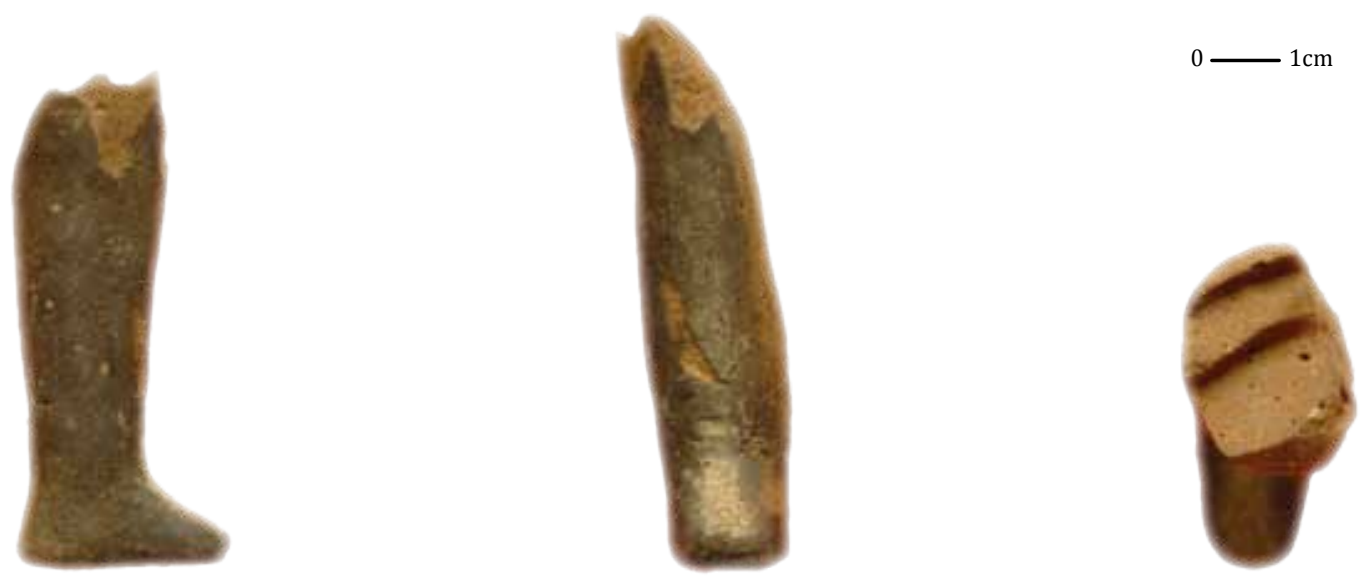

SI. 3: Pavlovac-Čukar - fragment noge figurine sekundarno korišćen kao alatka (foto: R. Drašković). 
SI. 4: Vinča - keramički disk sa perforacijom u centru (dokumentacija Vinča projekta).

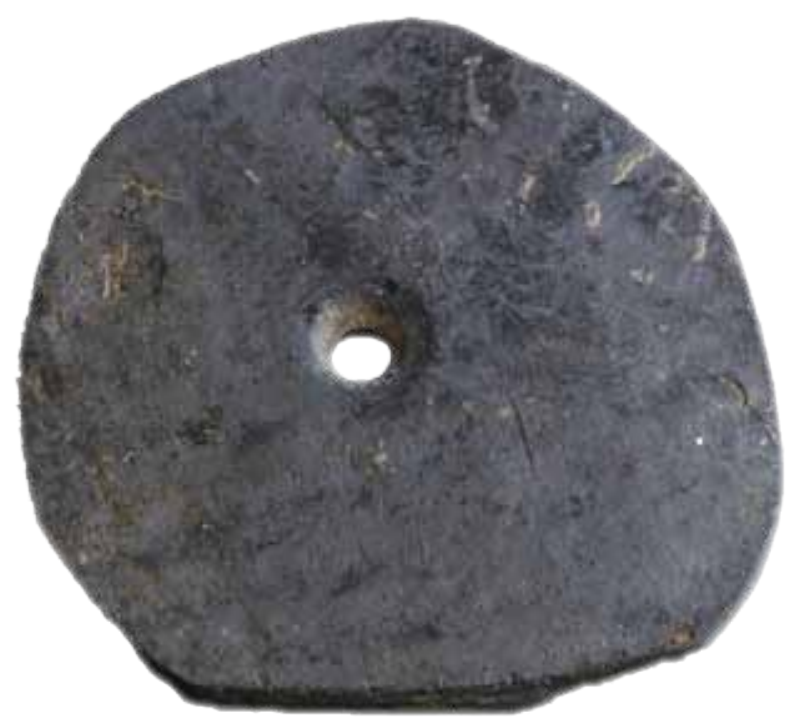

kao alatku, stopalo bi predstavljalo proksimalni kraj - neku vrstu drške, dok bi zona oko kolena predstavljala distalni kraj i oštećenjima njen najizloženiji deo. Od stopala naviše oštećenja postaju sve intenzivnija, pa je prvobitna površina potpuno uklonjena i zaravnjena abrazivnim pokretom. U predelu kolena nalaze se dva duboka žleba trougaonog preseka, a vidljive su i rupice od ispalih sitnijih primesa, što ukazuje na abraziv veće tvrdoće od keramike. Prema jedva vidljivim brazdama, čini se da je pokret u kome je alatka korišćena bio pravilan, u pravcu goredole, ali je alatka držana u blago kosom položaju. Prema izgledu oštećenja i njihovom položaju, zasad se može pretpostaviti da je upotrebljena za izradu ili glačanje alatki od kosti, verovatno šila. Recikliranje delova nogu figurina na Pavlovcu zasad je registrovan na još dva primerka sa sličnim tragovima upotrebe, što govori o tome da ovo nije izolovan slučaj, već da se radi o uobičajenoj praksi. Ovakva upotreba delova figurina zasad nije registrovana na drugim neolitskim lokalitetima, pa primerci sa Pavlovca otvaraju niz novih pitanja, koja se tiču namene figurina i njihovog značenja u neolitskom društvu, tim pre što se one najčešće dovode u vezu sa kultom i ritualnim radnjama. Na ovom mestu, međutim, valja biti veoma oprezan. Pavlovac je višeslojan lokalitet, dodatno oštećen oranjem, a kontekst u kome su figurine pronađene ne pruža pouzdane elemente za datovanje, pa postoji mogućnost da su one sekundarno korišćene u kasnijim praistorijskim periodima. Mogućnost da su gvozdenodopski stanovnici Pavlovca koristili fragmente neolitskih figurina na koje su lako mogli naići tokom svakodnevnih aktivnosti, takođe otvara zanimljiva pitanja u vezi s praksama sekundarne upotrebe. Sličan običaj - da se predmeti ranijih perioda recikliraju i ponovo ulaze u upotrebu potvrđen je i na ranosrednjovekovnim lokalitetima u Đerdapu: na Ušću Slatinske reke su opeke ili njihovi fragmenti korišćeni za oblikovanje šila (Jovanović et al. 1986), a na Pontesu su rimske opeke dodatno oblikovane i perforirane, pa su služile kao tegovi (Garašanin et al. 1984: 45).

Još od vremena neolita pa nadalje u arheološkom materijalu se javljaju diskovi - ili, kako se često u arheološkom žargonu može čuti - tzv. "žetoni”. Radi se o fragmentima trbuha posuda, gotovo pravilnog kružnog oblika, čija namena nije uvek sasvim jasna. Oni posle pečenja, a po svoj prilici i posle preoblikovanja, mogu biti perforirani u centru i u takvim slučajevima se obično tumače kao pršljenci za vreteno (sl. 4). Takvo objašnjenje još uvek nije sasvim pouzdano, s obzirom na to da, bar u slučaju primeraka sa centralnog Balkana, nisu identifikovani eventualni tragovi upotrebe - vezivanja. U materijalu sa kasnoneolitske Vinče keramički diskovi su takođe prisutni. ${ }^{1} \mathrm{U}$ njihovom centru vidljivi su tragovi upotrebe u vidu oštrih, tankih ureza u različi-

${ }^{1}$ Materijal nije publikovan. 
tim pravcima. S obzirom na to da se radi o fragmentima većih posuda, oni su potpuno ravni, a urezi verovatno potiču od neke izuzetno oštre alatke (po svoj prilici od okresanog kamena), pa se sa velikom sigurnošću mogu objasniti kao radna površina, odnosno podloga za sečenje, slično današnjim daskama za meso. Takva upotreba fragmenata većih posuda potvrđena je i etnoarheološkim istraživanjima (Deal 1998: 109). I na praistorijskim lokalitetima iz drugih delova sveta, glineni diskovi su takođe uobičajena vrsta nalaza. Ukoliko se radi o primercima malih dimenzija, obično se tumače kao neka vrsta sredstva za prebrojavanje ili predmeta na kojima se nešto okretalo (rollers) (Knight 2010: 151-152). Na rimskim lokalitetima uobičajeni su nalazi diskova izrađenih od fragmenata amfora, koji su korišćeni kao zatvarači - obturamenta (Peña 2007: 153-154). Stavljani su na otvor posuda, a zatim "zapečaćeni" malterom, gipsom ili glinom. U ovu svrhu upotrebljavani su i fragmenti opeka i tegula, ali i fragmenti posuda kojima ivice nisu posebno modifikovane. Ovi nalazi su posebno česti na lokalitetima brodoloma, gde su nalaženi in situ - na otvoru amfora.

Keramički diskovi - pessoi - takođe su veoma česti nalazi na lokalitetima kasnog geometrijskog i ranog arhajskog perioda Grčke, ali i rimskog perioda. Tumačeni su na različite načine - kao poklopci, u slučajevima kada su perforirani, kao čepovi (Brann 1961: 342) ili kao pioni za igru na tabli (cf. Kurke 1999: 263). Međutim, njihova izuzetna raznovrsnost u dimenzijama, kao i brojnost ukazali su na to da su ti predmeti bili veoma široko korišćeni i da objašnjenje da se radi o pionima za igru nije dovoljno, a ni jedino rešenje. S obzirom na to da je najveći broj pronađen na mestima na kojima se odlagalo smeće, ponuđeno je još jedno, krajnje "ovozemaljsko" objašnjenje: da su korišćeni za brisanje, u vreme kada latrine sa tekućom vodom još nisu bile poznate (Papadopoulos 2002), mada se ova praksa po svoj prilici u grčkom svetu zadržala i za vreme rimske dominacije. Pretpostavlja se da su i neke od glinenih pločica (ostraka) korišćene u ovu svrhu, čime je korisnik mogao i bukvalno da "opogani" ime neprijatelja. S druge strane, abrazivna svojstva keramike su na delikatnim delovima tela izazivala i veoma nezgodne medicinske probleme (Charlier et al. 2002).

Drškama većih keramičkih posuda potrebno je posvetiti posebnu pažnju. Njihova funkcija kao sekundarnog morfološkog atributa u primarnoj upotrebi - kao dela posude kojim se ona pridržava, nosi ili kači vrlo često ostaje njihova namena i kada se koriste u sekundarnom kontekstu. Etnoarheološka istraživanja pokazuju da se drške velikih posuda koriste pričvršćene na zidovima prostorija da bi se na njih kačili različiti predmeti u svakodnevnoj upotrebi (Deal 1998: 108). Na majanskom naselju Seren (Cerén) u El Salvadoru, koje je početkom VI veka nove ere stradalo u vulkanskoj erupciji, otkrivene su drške velikih skladišnih posuda, koje su inkorporirane u zemljane zidove kuća ili privezane za stubove i potom premazane blatom (McKee 1999: 37-38). Najčešće se nalaze u uglovima dovrataka i služile su za pridržavanje vrata od pruća.

Fragmenti sekundarno korišćenih drški veoma su česti i na kasnoneolitskim vinčanskim lokalitetima. Ovoj vrsti nalaza dosad nije posvećena naročita pažnja, ali se, imajući u vidu njihovu brojnost na eponimnom lokalitetu može pretpostaviti da su deo uobičajenog inventara vinčanskih kuća. Zbog zaobljenih ivica, međutim, one se često pogrešno nazivaju glačalicama, čime se podrazumeva da su namerno preoblikovane u alatke. Njihov nepravilni oblik, međutim, pokazuje da na njima nije bilo intervencija kojim bi se njihov oblik "doterao", a zaobljene, glatke ivice zapravo potiču od abrazivnog dejstva vode. Štaviše, nalaz velike koncentracije takvih drški u okviru jedne od vinčanskih kuća, nedvosmisleno pokazuje da su one korišćene kao tegovi za ribarske mreže (sl. 5). Međutim, kao što je već nekoliko puta istaknuto, fragmenti tokom svog upotrebnog veka mogu da prelaze iz jednog u drugi vid sekundarne upotrebe. Tako su poznate i drške - tegovi sa tragovima upotrebe na delu ivice, koji ukazuju na aktivnosti struganja po nekoj tvrdoj površini. Tako je, pošto je prestala da bude korišćena kao teg za mreže, drška postala nespecijalizovana alatka, verovatno za jednokratnu upotrebu. Upotreba drški amfora kao alatki za mrvljenje ili glačanje potvrđena je i u rimskom periodu (Peña 2007: 152). 


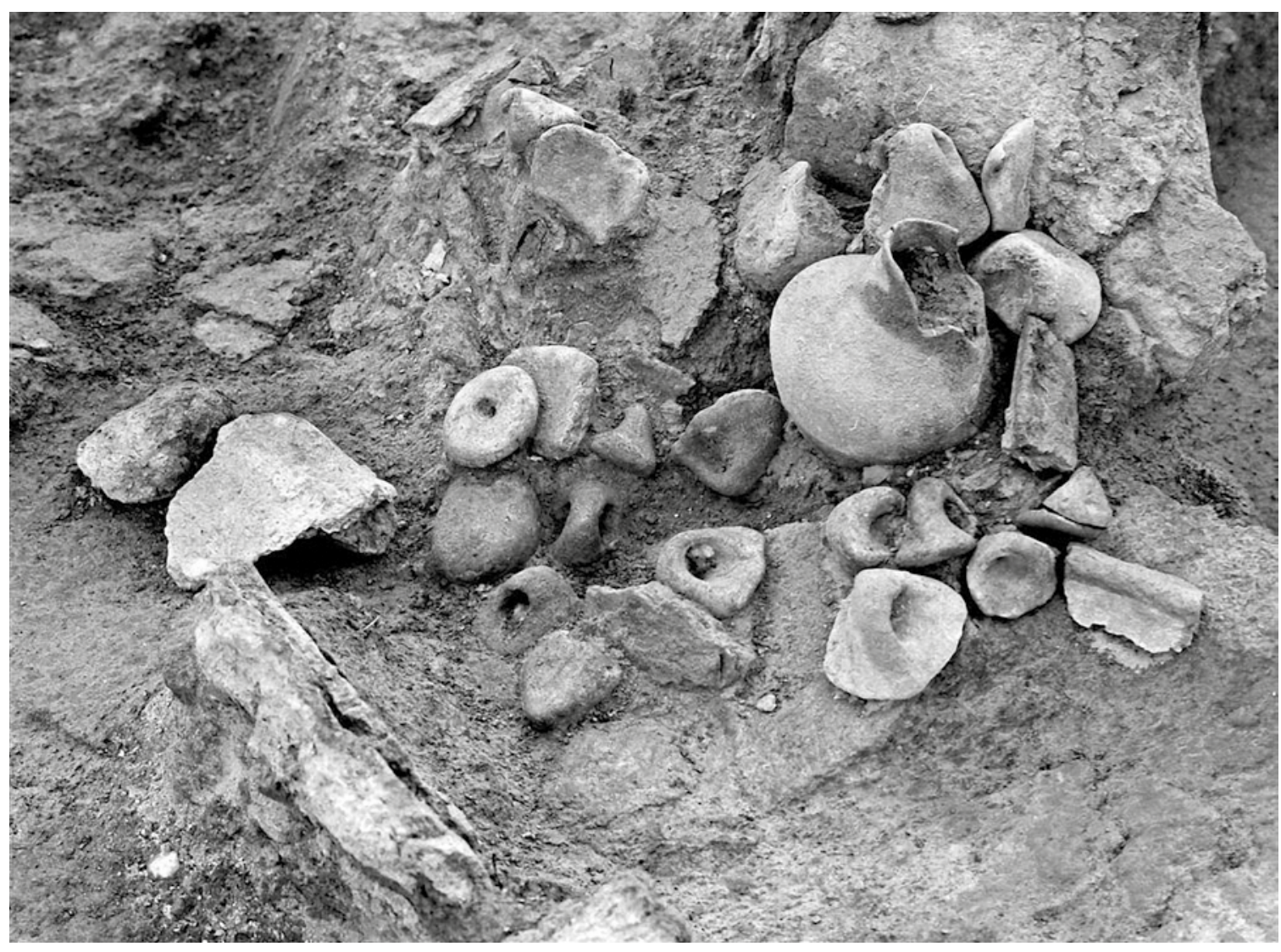

Keramika kao sirovina

Upotreba keramike kao sirovine možda najviše odgovara onome kako reciklažu doživljavamo danas. Mrvljena keramika od najstarijih perioda imala je široku upotrebu u izradi grnčarije i maltera. Tucana keramika - šamot ili grog - koristi se kao primesa u glinenoj masi gotovo na svim meridijanima, u širokom hronološkom rasponu. Razlozi za njenu upotrebu su mnogobrojni: lakše ih je izmrviti nego druge vrste mineralnih primesa (kamenčiće), njegova upotreba je ekonomična, jer se tako smanjuje potrebna količina osnovne sirovine, ali je još važnija njegova zapreminska postojanost. Pošto se radi o već pečenoj keramici, šamot ima potpuno iste termičke karakteristike kao i masa u koju je umešan (Rye 1981: 31), pa ima isti koeficijent termičkog širenja kao i ostatak mase (Arnold 1985: 24), što keramiku čini otpornijom na termičke i mehaničke pritiske, a zahvaljujući činjenici da čestice keramike apsorbuju vlagu, grog doprinosi i lakšem sušenju (cf. Miloglav 2016: 31-32). Upotreba groga, na primer, uobičajena je na keramici tzv. Potiske kulture u Panoniji, u vučedolskoj keramici (Miloglav 2016), on je u manjem obimu korišćen i u izradi vinčanske keramike. Mrvljena keramika može se koristiti kao sirovina koja se meša s blatom i tako se formira lep za gradnju kuća (Bredwa Mensah 1996: 56). U rimsko vreme upotreba mrvljene keramike i opeke takođe je bila sasvim uobičajena u izradi maltera, na primer u tzv. opus signinum, sastavljenom od kreča i samlevene opeke, koji je naročito korišćen kao izolacija od vlage, a potvrđen je, između ostalog, i u Singidunumu (Vujović 1997). 


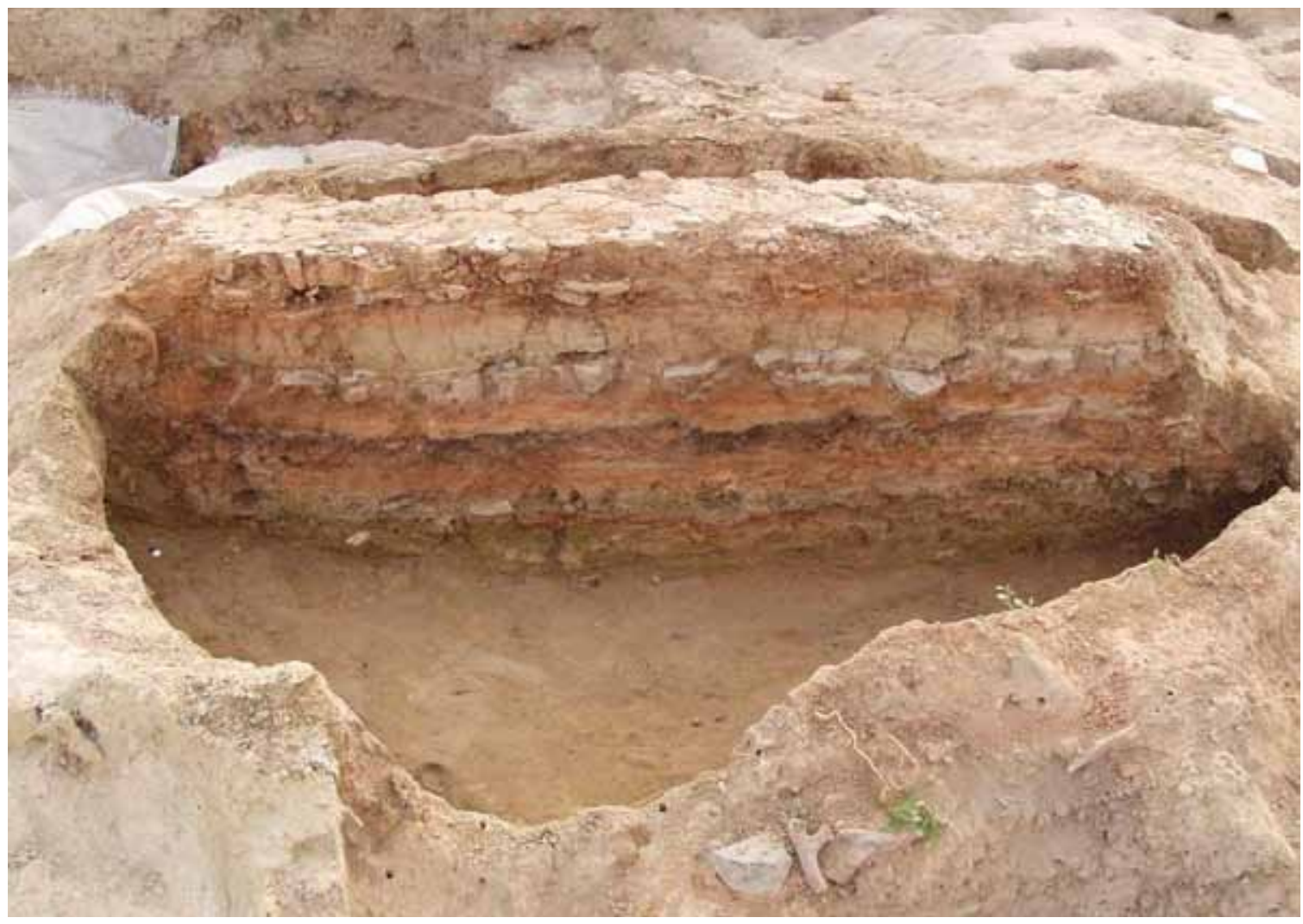

Keramika kao građevinski materijal

Fragmenti keramičkih posuda, ali i drugih predmeta od keramike takođe su korišćeni i kao građevinski materijal. Etnoarheološka istraživanja pokazala su da se fragmenti keramike koriste za popločavanje staza i dvorišta, popunjavanje pukotina u dimnjacima, kao opterećenje kojim se ojačava krov od trske ili granja (Deal 1998). Takve vidove upotrebe veoma je teško prepoznati u arheološkom zapisu i oni se, uz retke izuzetke (Sullivan 1989), zasad mogu samo pretpostaviti. Tokom procesa izrade keramike, fragmentima se često popločava osnova jama, za pečenje, a takođe se koriste i kao zaštita posuda od užarenog goriva (Deal \& Hagstrum 1995: 117), jer je keramika dobar izolator. U vreme kasnog neolita, fragmenti keramike široko su korišćeni za fundiranje osnova ognjišta ili peći. Peći u Vinči često imaju i po nekoliko slojeva obnove podnice od keramičkih fragmenata (Vuković 2015) (sl. 6). Za tu svrhu upotrebljavani su fragmenti većih posuda, ali je veoma česta upotreba "uglastih" komada - ramena bikoničnih zdela, kao i drški, verovatno kako bi se sav materijal bolje povezao da bi se oformila čvrsta podnica. Zanimljivo je da se u materijalu iz supstrukcija peći često javljaju fragmenti koji su korišćeni kao alatke ili drške-tegovi za mreže. Oni su imali složen upotrebni ciklus, a svoj upotrebni vek završili su kao građevinski materijal. U antičko vreme, posude i njihovi delovi takođe su korišćeni kao arhitektonski elementi: za ventilaciju ili inkorporirani u zidove kao police (Południkiewicz 2014: 141), različite vrste umetaka u piscinama ili zidovima, konstruktivni elementi, kao cevi za libaciju u grobovima (Peña 2007), a velike količine ulomaka keramičkog otpada zasipane su kao drenažni slojevi (Lipovac Vrkljan 2011). 
Dosad su prikazane različite upotrebe predmeta od keramike u svakodnevnim aktivnostima, ali se posude ili njihovi fragmenti mogu koristiti i u ritualnim radnjama i u posmrtnim običajima i tada imaju posebno simboličko značenje. Plinije Stariji, na primer, navodi da su sveštenici boginje Kibele - gali - koristili fragmente samijske keramike (terra sigillata) za ritualno kastriranje ${ }^{2}$, jer im njena upotreba omogućava da izbegnu štetne posledice, pa se tako keramici pripisuju neka posebna svojstva. U nekim delovima sveta se polomljeni delovi nekorišćenih posuda koriste kao ukrasi oko vrata, uz verovanje da deluju kao amajlije protiv zlih sila (Manibabu 2010: 7). U južnom Meksiku se oštećene ritualne posude i njihovi fragmenti, kao i fragmenti sakupljeni sa arheoloških lokaliteta čuvaju oko kućnih oltara (Deal \& Hagstrum 1995: 118), a ponekad se koriste kao kadionice za vreme ceremonija izlečenja.

Iz vremena metalnih doba široko je poznat običaj da se pokojnici sahranjuju umesto u urnama, u utilitarnim posudama, koje su korišćene u svakodnevnim poslovima u domaćinstvu, kao što su zdele, lonci za kuvanje, pehari i sadžaci (na primer Vranić 2002), a u rimsko vreme je takođe bilo uobičajeno da se amfore ili njihovi delovi koriste kao sarkofazi za sahranjivanje ili kao osuariji za pohranjivanje kosti i pepela posle kremacije (Peña 2007: 164-166). Upotreba fragmenata amfora kao delova grobne konstrukcije poznata je i sa niza grobova u Viminacijumu (Golubović 2017).

Keramika je u tradicionalnim društvima povezana sa plodnošću, pa je izrada keramičkog posuđa ujedno i metafora za životni ciklus čoveka, u kome svi koraci u izradi simbolišu različite stupnjeve u životu ljudi (rađanje, odrastanje, zrelost), pa shodno tome keramički fragmenti simbolišu smrt. Tako, na primer, udovice u žalosti u nekim delovima Afrike moraju da jedu iz fragmenata keramike, a ne iz celih posuda (Nangendo 1996: 73, 76; cf. Vuković 2013a). Da keramički fragmenti simbolizuju prestanak života ne samo ljudi, već i čitavih naselja pokazuje slučaj puebla Kodistas (Chodistaas) u Arizoni (XIII vek nove ere) (Reid 2006: 77-79) Posle veoma kratkotrajnog života naselje je namerno zapaljeno, a vatra je ugašena zasipanjem velike količine ulomaka posuda. Ritualnim «kremiranjem» puebla i njegovim pokopavanjem nasipanjem keramike (Montgomery 1992), pueblo je simbolički «umro», a zatim je napušten.

U neindustrijskim društvima iz različitih delova sveta, keramičke posude predstavljaju i simbol plodnosti (Forni 2007), jer se izrađuju od zemlje ${ }^{3}$ koja je izvor života, oblikom podsećaju na matericu, a sadrže hranu neophodnu za život (Barley 1994: 53; Aguilar 2007), pa se posude ili njihovi fragmenti koriste u običajima vezanim jednako za rođenje kao i za smrt. U mnogim delovima Srednje Amerike potvrđen je običaj sahranjivanja placente u utilitarnim keramičkim posudama (Deal 1998: 111). U južnim delovima Afrike polomljene posude su korišćene za vodu kojom je kupana novorođenčad neposredno posle porođaja. U tim prilikama one su imale simboličku ulogu ritualnog pročišćenja, a novorođena beba je izlagana dimu različitih lekovitih trava koje su paljene u fragmentima keramike (Boeyens et al. 2009: 224-225). Zato možda nije čudno što se keramičke posude često koriste i za sahranjivanje novorođenčadi i dece, na širokom prostoru i u hronološkom rasponu. Takva praksa pojavljuje se već s prvim zemljoradničkim zajednicama, u vreme ranog neolita - na Levantu, ali se sahrane u keramičkim posudama sporadično javljaju i na prostoru jugoistočne Evrope, u kulturama Karanovo I i Kremenik-Anzabegovo (Bačvarov 2004). Sekundarna upotreba posuda za pripremu, čuvanje i konzumiranje hrane za sahranjivanje objašnjena je religijskim shvatanjima ranih zemljorad-

\footnotetext{
${ }^{2}$ http://www.perseus.tufts.edu/hopper/text?doc=Perseus\%3Atext\%3A1999.02.0137\%3Abook\%3D35\%3Achapter\%3D46

${ }^{3}$ Glina je mineral, ali činjenica da se u prirodi nalazi u vidu sedimenta uslovila je da se izjednačava zemljom, i to ne samo u neindustrijskim društvima - čak se i u arheološkoj literaturi, posebno starijoj, često pogrešno navodi da je keramika izrađena od zemlje.
} 
nika u kojima je postojala čvrsta veza između života i smrti, pa su posude (koje sadrže hranu neophodnu za život) na simboličkom planu predstavljale matericu koja je omogućavala ponovno rođenje. Sahranjivanje dece u pitosima na Kritu glavom naniže, u položaju fetusa, takođe simbolički predstavlja njihovo ponovno rođenje (McGeorge 2013). I u južnoj Africi potvrđena je praksa sahranjivanja novorođenčadi u oštećenim posudama - loncima za kuvanje, o čemu svedoče intenzivni tragovi ugljenisanih naslaga, na čijem dnu je sa unutrašnje strane probijena rupa (Boeyens et al. 2009). U tim situacijama posuda je simbolizovala matericu, a probijena rupa je simbolički omogućavala ženi da ponovo zatrudni. Jedinstvena praksa upotrebe keramičkih posuda sa naknadno probijenim rupama u posmrtnom ritualu na lokalitetima kulture Mimbres, koja je cvetala tokom X-XI veka na prostoru Novog Meksika ima nešto drugačije značenje i simboliku. Pokojnicima su na glavu polagane zdele, raskošno slikane crno-belim motivima (Fewkes 1989), koje su sekundarno korišćene u funerarnom kontekstu. Rupe probijene na posudama (kill-holes), koje su nekad izvedene tek kad je zdela bila na glavi pokojnika (Plog 1997: 92), predstavljale su put kojim je duša pokojnika prelazila na onaj svet (Shafer 1995: 41).

Predmeti od keramike mogu se sekundarno koristiti i reciklirati na različite načine i u različitim situacijama - od sasvim utilitarnih i svakodnevnih aktivnosti, do kultnih i ritualnih radnji. Za razliku od današnjeg shvatanja recikliranja kao prerade otpada i odgovornog odnosa prema prirodnom okruženju, recikliranje predmeta u prošlosti posledica je sasvim drugačijih uzroka i motiva. Ponekad, kao u slučaju ranije pomenute rimske radionice za preradu posuđa, razlozi mogu biti otežana nabavka kao posledica izolovanosti i udaljenosti od distributivnih centara, ali se u nekim slučajevima kao razlog za prepravke ne isključuje ni siromaštvo (Południkiewicz 2014). Ponovna upotreba i recikliranje obično se smatraju adaptivnom ekonomskom strategijom kojom se smanjuju potrebe domaćinstva za snabdevanjem (Deal \& Hagstrum 1995: 112). Tako ove prakse pokazuju veoma pragmatičan i praktičan odnos po kome se sve može upotrebiti za neku drugu svrhu, posebno ukoliko se radi o velikim količinama dostupnog "otpada", kao što je to keramika: umanjuje se potrebna količina uloženog truda i rada za izradu novih predmeta ili njihovu nabavku i koristi se ono čega ima u izobilju. Ponekad bi to mogla biti posledica prinude - u slučaju vinčanske keramike pretpostavljena je stresna situacija u kojoj su druge sirovine (pre svega kamene) bile nedostupne (Vuković 2013b). S druge strane, prepoznavanje pogodnih svojstava keramike kao sirovine ili građevinskog materijala pokazuje posedovanje tehnološkog i tehničkog znanja, pa je u tim slučajevima ekonomičnost upotrebe keramike u prvom planu. S obzirom na to da je keramika korišćena u čitavom nizu situacija, ona se, u periodu između primarne i sekundarne upotrebe morala negde skladištiti, pa je u arheološkoj i etnoarheološkoj literaturi formulisan pojam privremenog odbacivanja (Deal 1998: 119-120; cf. Vuković 2015), koji podrazumeva postojanje mesta na kojima su se oštećene posude, fragmenti i drugi predmeti skladištili do njihove sekundarne upotrebe. Takva mesta su dobro dokumentovana u etnoarheologiji, međutim tokom arheoloških iskopavanja, naročito praistorijskih perioda, veoma ih je teško prepoznati. Identifikovanje različitih vidova sekundarne upotrebe i rekonstrukcija aktivnosti i konteksta u kojima se ona odvijala nije uvek jednostavno, ni lako. Zato je potrebno ponovo skrenuti pažnju na njihov značaj u budućim istraživanjima jer upotrebni ciklus keramike predstavlja važnu kariku u razumevanju zajednica u prošlosti i pre svega, složenog suživota ljudi i keramike. 
Aguilar, L. B.. 2007. Metaphors, Myths and Making Pots: Chewa Clay Arts. African Arts 40 (1). 64-70.

Arnold, D. E. 1985. Ceramic Theory and Cultural Process. Cambridge Univesrity Press. Cambridge.

Bačvarov, K. 2004. The Birth-Giving Pot: Neolithic jar burials in southeast Europe. U/In: Prehistoric Thrace. Proceedings of the International Symposium in Stara Zagora, 30.09-

04.10.2003. (ur./eds. V. Nikolov, K. Bačvarov \& P. Kalchev). Institute of Archaeology with Museum - BAS, Regional Museum of History. Stara Zagora. 151-160.

Baeten, J., Deforce K., Challe, S., De Vos, D. \& Degryse, P. 2014. Holy Smoke in Medieval Funerary Rites: Chemical Fingerprints of Frankincense in Southern Belgian Incense Burners. Plos One 9 (11), e113142.

Barley, N. 1994. Smashing Pots: Feats of Clay from Africa. British Museum Press. London.

Boeyens, J., van der Ryst,M., Coetzee, F., Steyn, M. \& Loots, M. 2009. From uterus to jar: the significance of an infant pot burial from Melora Saddle, an early nineteenth-century African farmer site on the Waterberg Plateau. Southern African Humanities 21. 213-238.

Brann, E. 1961. Protoattic well groups from the Athenian Agora. Hesperia 30 (4). 305-379.

Bredwa-Mensah, Y. 1996. The production and Use Patterns of Ga Pottery in the Lower Densu Valley, Western Accra Plains, Ghana. Papers from the Institute of Archaeology 7. 47-58.

Charlier, P., Brun, L., Prêtre, C., \& Huynh-Charlier I. 2012. Toilet hygiene in the classical era. British Medical Journal 2012; 345: e8287.

Deal, M. 1998. Pottery Ethnoarchaeology in the Central Maya Highlands. The University of Utah Press. Salt Lake City.

Deal, M., \& Hagstrum, M. B.. 1995. Ceramic Reuse Behavior among the Maya and Wanka: Implications for Archaeology. U/In: Expanding archaeology. (ur./eds. J. M. Skibo, W. H. Walker \& A. E. Nielsen). The University of Utah Press. Salt Lake City. 111-125.

Garašanin, M., Vasić, M, R. \& Marjanović-Vujović, G. 1984. Trajanov most - Castrum Pontes. Đerdapske sveske 2. 25-84.

Fewkes. J. 1989. The Mimbres. Art and Archaeology. Avanuy Publishing Inc. Albuquerque.

Forni, S. 2007. Containers of life: pottery and social relations in the Grasslands (Cameroon). African Arts 40 (1). 42-53.

Frank, B. E. 1994. More than Wives and Mothers. The Artistry of Mande Potters. African Arts 27 (4). 26-37, 93-94.

Gosselain, O. P. 1992. Technology and Style: Potters and Pottery Among Bafia of Cameroon. Man, New Series 27 (3). 559-586.

Golubović, S. 2017. Viminacijumske nekropole, usmeno saopštenje, Mnemosynon Firmitatis 70 godina Arheološkog Instituta, Beograd, 7. jun 2017. Srpsko arheološko društvo. XL Skupština i godišnji skup i proslava 70 godina Arheološkog instituta - Program, izveštaji i apstrakti. Beograd: Srpsko arheološko društvo. 139-140.

Hally, D. J. 1983. The Interpretive potential of pottery from domestic contexts. Midcontintental Journal of Archaeology 8 (2). 163-196.

Jovanović, A., Korać, M. \& Janković, Đ. 1986. L`Embouchure de la Rivière Slatinska reka. Đerdapske sveske 3. 378-400.

Knight, V. J. Jr. 2010. Mound excavations at Moundville: Architecture, elites, and social order. The University of Alabama Press. Tuscaloosa. 
Kurke, L. 1999. Ancient Greek Board Games and How to Play them. Classical Philology 94 (3). 247-267.

Lipovac Vrkljan, G. 2011. Lokalna keramičarska radionica Seksta Metilija Maksima u Crikvenici - Crikveničke amfore ravnog dna. U/In: Rimske keramičarske i staklsarske radionice - proizvodnja i trgovina na jadranskom prostoru. Zbornik I međunarodnog arheološkog kolokvija Crkvenica, 23-24. listopada 2008. (ur/eds. G. Lipovac Vrkljan, I. Radić Rossi \& B. Šiljeg). Institut za arheologiju, grad Crikvenica i Muzej grada Crikvenice. Zagreb. 3-18.

Lopez Varela, S., Van Gijn, A. \& Jacobs, L. 2002. De-mystifying Pottery Production in the Maya Lowlands: Detection of Traces of Use-Wear on Pottery Sherds through Microscopic Analysis and Experimental Replication. Journal of Archaeological Science 29. 1133-1147.

Manibabu, M. 2010. Ethnoarchaeology of Ceramic Reuse and Discard Behaviour of the Andro of Manipur. The Oriental Anthropologist 10 (2). 155-167.

McKee, B. R. 1999. Household archaeology and cultural formation processes: Examples from the Cerén site, El Salvador. U/In: The Archaeology of Household Activities. (ur./ed. P. M. Allison). Routledge. London. 30-42.

Mcgeorge, P. J. P. 2013. Intramural infant burials in the Aegean Bronze Age: Reflections on symbolism and eschatology with particular reference to Crete. U/In: Le mort dans la ville, Pratiques, contextes et impacts des inhumations intra-muros en Anatolie, du début de l'Âge du Bronze à l'époque romaine. (ur./ed. O. Henry). Institut Français d`Études Anatoliennes. Istanbul. 1-19.

Merkyte, I. 2005. Pottery as a Source of Information. Acta Archaeologica 76 (1). 73-94.

Plog, S. 1997. Ancient Peoples of The American Southwest. Thames and Hudson. London.

Miloglav, I. 2016. Keramika u arheologiji - lončarstvo vučedolske kulture na vinkovačkom području. Gradski muzej Vinkovci, Filozofski fakultet Sveučilišta u Zagrebu.Vinkovci-Zagreb.

Montgomery, B. 1992. Understanding the formation of the archaeological record: Ceramic variability at Chodistaas Pueblo. Phd Thesis Arizona: The University of Arizona.

Nangendo, S. 1996. Pottery Taboos and Symbolism in Bukusu Society. Western Kenya. African Study Monographs 17 (2). 69-84.

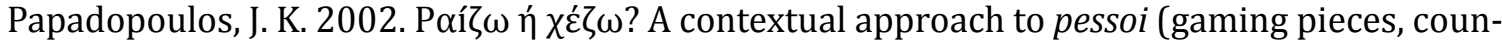
ters, or convenient wipes?). Hesperia 71. 423-427.

Peña, T. 2007. Roman Pottery in the Archaeological Record. Cambridge University Press. Cambridge.

Południkiewicz, A. 2014. Poverty or economy? A ceramological perspective. U/In: La pauverté en Grèce ancienne. Formes, représentations, enjeux. (ur./eds. E. Galbois \& S. Rougier-Blanc). Ausonius Scripta Antiqua 57. Bordeaux. 139-144.

Reid, J. 2006. A Grasshopper Perspective on the Mogollon of the Arizona Mountains. U/In: Dynamics of Southwest Prehistory. (ur./eds. L. S. Cordell \& G. J. Gumerman). The University of Alabama Press. Tuscaloosa. 65-97.

Rye, Owen S. 1981. Pottery Technology. Taraxacum.Washington D. C.

Schiffer, M. B. 1983. Toward the Identification of Formation Processes. American Antiquity 48 (4). 675-706.

Schiffer, M. B. 1987. Formation Processes of the Archaeological Record. University of New Mexico Press. Albuquerque.

Shafer, H. J. 1995. Architecture and Symbolism in Transitional Pueblo Development in the Mimbres Valley, SW New Mexico. Journal of Field Archaeology 22 (1). 23-47.

Skibo, J. M. 1992. Pottery Function: A Use-Alteration Perspective. Plenum Press. New York. Sullivan, A. P. 1989. The Technology of Ceramic Reuse: Formation Processes and Archaeological Evidence. World Archaeology 21 (1). 101-114. 
Sullivan, A. P., Skibo, J. M. \& Van Buren, M. 1991. Sherds as Tools: The Roles of Vessel Fragments in Prehistoric Succulent Plant Processing. North American Archaeologist 12 (3). 243-255.

Van Gijn, A. \& Hofman, C. 2008. Were they used as tools? An exploratory functional study of abraded [ptsherds from two pre-colonial sites on the island of Guadeloupe, northern Lesser Antilles. Carribean Journal of Science 44 (1). 21-35.

Vranić, S. 2002. Belegiš - Stojića gumno - nekropola spaljenih pokojnika. Muzej grada Beograda. Beograd.

Vujović, M. 1997. Prilog proučavanju antičkog zidnog slikarstva i štuko dekoracije na tlu Singidunuma. Singidunum 1.169-179.

Vuković, J. 2013a. Ženska tehnologija: identitet neolitskih majstora-grnčara. Etnoantropološki problemi 8 (1). 295-316.

Vuković, J. 2013b Fragmenti kao alatke u kasnoneolitskoj Vinči. Starinar 63. 191-207.

Vuković, J. 2015. Secondary Use, Reuse and Recycling of Ceramic Vessels: Evidence from Late Neolithic Vinča. Arhaika 3. 111-126. 